\title{
Studi Eksperimen Pengaruh Variasi Inhibitor dan Konsentrasi Inhibitor terhadap Laju Korosi dan Penentuan Efisiensi Inhibisi pada Baja Tulangan Beton ST 42 di Kondisi Lingkungan Laut
}

\author{
Bayu Mahardika, Herman Pratikno, dan Hasan Ikhwani \\ Jurusan Teknik Kelautan, Fakultas Teknologi Kelautan, Institut Teknologi Sepuluh Nopember (ITS) \\ Jl. Arief Rahman Hakim, Surabaya 60111 Indonesia \\ e-mail: hermanp@oe.its.ac.id
}

\begin{abstract}
Abstrak - Korosi pada logam adalah masalah yang tidak bisa dihindari, hanya bisa dihambat. Masalah ini harus diperhatikan secara khusus, karena bisa berdampak pada kerugian materi maupun kerugian teknis. Salah satu cara yang digunakan untuk menghambat korosi adalah dengan penambahan inhibitor. Seperti pada penelitian yang dilakukan pada tugas akhir ini, meneliti pengaruh variasi inhibitor dan konsentrasi inhibitor terhadap laju korosi dan penentuan efisiensi inhibisi pada baja tulangan beton ST 42 di kondisi lingkungan laut. Inhibitor yang akan digunakan adalah sodium nitrit, asam askorbat, dan asam karboksilat, dan variasi konsentrasi inhibitornya adalah 100 ppm, 200 ppm, dan 300 ppm. Larutan induk media korosif yang digunakan adalah larutan garam dengan salinitas 3,5\%. Data dari hasil eksperimen menunjukkan bahwa semakin tinggi konsentrasi inhibitornya maka semakin rendah laju korosinya, serta didapatkan kondisi optimal pengaruh variasi inhibitor dan konsentrasi inhibitor terhadap laju korosi pada baja tulangan ST 42 di kondisi lingkungan laut yang efisiensi inhibisinya tertinggi adalah baja tulangan beton ST 42 pada beton bertulang menggunakan inhibitor sodium nitirt dengan konsentrasi 300 ppm, yaitu sebesar 0,37665 \%.
\end{abstract}

Kata Kunci-Korosi, baja tulangan beton, laju korosi, efisiensi inhibisi.

\section{PENDAHULUAN}

$\mathrm{K}$ OROSI dapat didefinisikan secara umum sebagai pengrusakan bahan oleh lingkungannya, Bahri (2007) ${ }^{[1]}$ menyatakan bahwa pengrusakan yang dimaksud adalah degradasi atau penurunan mutu logam akibat reaksi elektrokimia redoks atau reduksi oksidasi suatu logam dengan lingkungan dimana logam itu berada. Korosi dapat menyebabkan kerugian materi maupun kerugian teknis. Dari sisi materi, biaya perawatan akibat korosi dapat diestimasikan mencapai 40 \% dari keseluruhan total biaya perawatan. Dari sisi teknis, contohnya adalah robohnya bangunan yang dapat mengancam keselamatan manusia.

Beton bertulang (reinforced concrete) merupakan suatu bahan konstruksi yang biasa digunakan untuk membuat bangunan. Beton bertulang ini merupakan gabungan dari beton dan baja tulangan yang didesain khusus untuk memperkuat beton pada suatu konstruksi bangunan. Juliawati (2003) ${ }^{[2]}$ menyatakan bahwa beton adalah material campuran dari agregat, semen, dan air, yang memiliki kekuatan yang baik terhadap tekan, sedangkan baja tulangan pada beton bertulang ini memiliki kekuatan yang baik terhadap tarik.
Herdiansjah (2003) ${ }^{[3]}$ menyatakan bahwa ion-ion korosif yang masuk ke dalam beton bertulang itu dapat menyebabkan korosi pada baja tulangan serta rusaknya struktur beton. Struktur beton bertulang yang hancur karena serangan korosi ini membutuhkan biaya yang sangat besar untuk memperbaikinya. Korosi pada baja tulangan ini harus diperhatikan secara khusus. Oleh karena itu dicari solusi untuk mengatasi masalah ini.

Beberapa cara yang dapat memperlambat laju reaksi korosi antara lain dengan cara pelapisan permukaan logam agar terpisah dari media korosif, membuat paduan logam yang cocok sehingga tahan korosi, dan dengan penambahan zat tertentu yang berfungsi sebagai inhibitor reaksi korosi (Surdia, 1979) ${ }^{[4]}$. Teknologi penggunaan inhibitor untuk menghambat laju korosi pada baja tulangan telah banyak dikembangkan dan diteliti. Penelitian ini bertujuan untuk mengurangi dampak buruk yang terjadi akibat korosi pada baja tulangan beton.

Penambahan zat kimia atau yang disebut dengan inhibitor pada struktur beton bertulang merupakan salah satu cara untuk menghambat laju korosi. Pada penelitian yang telah dilakukan terdahulu, terdapat berbagai macam zat kimia yang digunakan sebagai inhibitor, diantaranya adalah penelitian yang dilakukan oleh Nikitasari (2014) ${ }^{[5]}$ menggunakan inhibitor sodium nitrit, Halomoan $(2003)^{[6]}$ dan Aziz (2013) ${ }^{[7]}$ menggunakan inhibitor asam askorbat, dan Juliawati (2003) ${ }^{[2]}$ menggunakan inhibitor asam karboksilat. Melalui tugas akhir ini akan dilakukan penelitian lebih lanjut tentang pengaruh inhibitor sodium nitrit, asam askorbat, dan asam karboksilat dengan variasi konsentrasi yang berbeda terhadap laju korosi dan efisiensi inhibisi pada material baja tulangan beton ST 42 pada kondisi larutan induk media korosif garam.

\section{DASAR TEORI}

\section{A. Beton}

Beton adalah istilah yang digunakan untuk menyatakan campuran antara semen, pasir (agregat halus), kerikil (agregat kasar), dan air yang mengeras menjadi padat menyerupai batu. Juliawati (2003) ${ }^{[2]}$ menjelaskan bahwa air dan semen akan membentuk pasta semen. Pasta semen ini merupakan bahan pengisi yang mengikat agregat halus dan agregat kasar secara keseluruhan. Rarasati (2003) ${ }^{[8]}$ menjelaskan bahwa agregat, baik pasir maupun kerikil memiliki fungsi sebagai zat pengisi dan penguat beton yang akan meningkatkan kekuatan beton. 


\section{B. Baja Tulangan}

Baja tulangan pada struktur beton berfungsi untuk menahan gaya tarik yang terjadi pada struktur beton bertulang (Herdiansjah, 2003) $^{[3]}$. Pada saat baja ditarik, terjadi beberapa kondisi, yaitu baja dapat bersifat elastis, plastis dan kemudian putus. Sifat elastis baja terjadi apabila baja ditarik kemudian dapat kembali ke bentuk semula. Sedangkan jika sudah mencapai sifat plastis maka baja tidak akan dapat kembali ke bentuk semula. Jika baja terus ditarik maka baja akan mengalami titik jenuh yang pada akhirnya akan putus.

\section{Korosi pada Baja Tulangan Beton}

Korosi adalah proses rusaknya material yang disebabkan karena adanya pengaruh dari lingkungan material tersebut (Fontana, 1986) ${ }^{[9]}$. Korosi baja tulangan beton merupakan faktor utama penyebab berkurangnya umut layanan struktur beton bertulang (Fardhyanti, 2004) ${ }^{[10]}$. Pada korosi terdapat dua reaksi elektrokimia yang dikenal sebagai reaksi anodik dan katodik. Hilangnya logam terjadi pada sisi anodik. Atom Fe larut dalam air yang ada di sekeliling baja lalu terion mennjadi $\mathrm{Fe}^{2+}$. Kemudian elektron mengalir di sepanjang baja dari potensial tinggi (sisi anodik) ke potensial rendah (sisi katodik). Supaya reaksi korosi dapat terus berlangsung maka jumlah elektron yang didonorkan dari daerah anodik harus sama dengan jumlah elektron yang diterima oleh daerah katodik. Dengan demikian, dibutuhkan molekul oksigen yang bereaksi pada daerah katodik sehingga dua atom Fe dapat terionisasi dan larut dalam daerah anodik. Oleh karena itu, jika pada daerah katodik tidak terdapat air dan oksigen maka proses korosi tidak akan terjadi. Selain itu juga terdapat air pori beton yang mengandung alkali dan $\mathrm{Ca}(\mathrm{OH})_{2}$ serta dapat menjadi sistem transportasi bagi aliran ion. Korosi bisa tidak terjadi jika dalam beton tidak ada air pori.

$$
\begin{aligned}
& \stackrel{\text { Reaksi Anoda: }}{\mathrm{Fe} \rightarrow \mathrm{Fe}^{2+}+2 \mathrm{e}^{-}} \\
& \mathrm{Fe}^{2+}+2 \mathrm{OH}^{-} \longrightarrow \mathrm{Fe}(\mathrm{OH})_{2} \\
& 4 \mathrm{Fe}(\mathrm{OH})_{2}+\mathrm{O}_{2}+\mathrm{H}_{2} \mathrm{O} \rightarrow 4 \mathrm{Fe}(\mathrm{OH})_{3} \\
& \rightarrow 2 \mathrm{Fe}_{2} \mathrm{O}_{3} \cdot \mathrm{H}_{2} \mathrm{O}+4 \mathrm{H}_{2} \mathrm{O} \text { (Karat) } \\
& \underset{\text { Reaksi Katoda: }}{\mathrm{O}} \\
& \mathrm{O}_{2}+\mathrm{H}_{2} \mathrm{O}+2 \mathrm{e}^{-} \longrightarrow 2 \mathrm{OH}^{-}
\end{aligned}
$$

\section{Analisa Laju Korosi Metode Weight Loss}

Metode ini dipakai berdasarkan pada kehilangan berat yang dialami logam sebagai akibat dari proses penetrasi ion agresif selama proses korosi. Proses korosi tersebut dihitung berdasarkan pada jangka waktu penelitian yang dilakukan. Jumlah kehilangan berat akibat korosi dapat dihitung menggunakan rumus yang ada pada ASTM G 31 - 72 $2^{[11]}$ sebagai berikut:

$$
\mathrm{CR}=\frac{R W W}{D W A W T}
$$

\section{E. Inhibitor}

Inhibitor adalah suatu bahan kimia yang ketika ditambahkan dalam jumlah konsentrasi yang tertentu pada suatu lingkungan, dapat secara efektif mengurangi laju korosi. Inhibitor bereaksi dengan permukaan logam yang terekspos dalam suatu lingkungan dan akan memberikan proteksi pada permukaan tersebut. Halomoan (2003) ${ }^{[6]}$ menjelaskan bahwa inhibitor bekerja dengan cara mengadsorpsi kedalam permukaan logam dan melindunginya dengan membentuk sebuah lapisan film.

Halomoan (2003) ${ }^{[6]}$ dan Nasution (2012) ${ }^{[12]}$ menyatakan bahwa efisiensi inhibisi dari suatu inhibitor dapat ditentukan dengan perhitungan sebagai berikut:

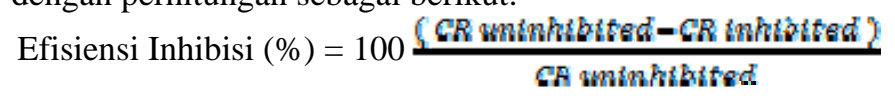

\section{METODOLOGI PENELITIAN}

Langkah-langkah penelitian pengerjan tugas akhir ini dapat dijelaskan sebagai berikut:

\section{A. Studi Literatur}

Tugas akhir ini diawali dengan pemahaman materi melalui apa yang didapatkan penulis di mata kuliah Korosi. Kemudian dilanjutkan dengan mempelajari buku, jurnal, proseding, dan tugas akhir terdahulu yang membahas tentang permasalahan yang berhubungan dengan tugas akhir ini. Literatur tersebut digunakan sebagai referensi dalam penulisan tugas akhir ini.

\section{B. Persiapan Spesimen Silinder Beton dan Pengujian Kuat Tekan Beton K 350}

Dalam penelitian tugas akhir ini, beton yang dipakai adalah beton mutu K 350 berumur 7 hari. Pengujian kuat tekan beton ini bertujuan untuk mengetahui kuat tekan yang dimiliki oleh beton mutu K 350 pada umur 7 hari tersebut. Pengujian ini dilaksanakan berdasarkan Buku Petunjuk Praktikum Teknologi beton dan Bahan Teknik Sipil ITS $^{[13]}$ yang mengacu pada ASTM C 39 $9^{[14]}$.

Bahan komposisi beton yang telah disiapkan, diaduk menggunakan mesin molen sampai tercampur rata. Kemudian adukan beton tersebut dicetak pada cetakan silinder berukuran diameter $15 \mathrm{~cm}$ dan tinggi $30 \mathrm{~cm}$. Spesimen yang telah berumur 7 hari siap untuk dilakukan pengujuan kuat tekan. Nilai kuai tekan beton 7 hari dapat dihitung dengan rumus berikut:

$$
\text { Kuat Tekan Beton } 7 \text { hari }=\frac{\mathrm{P}}{\mathrm{A}}
$$

Setelah nilai kuat tekan beton umur 7 hari didapatkan, kemudian nilai tersebut dapat dikorelasikan dengan tabel korelasi umur beton untuk mengetahui nilai kuat tekan beton dari rencana mutu beton yaitu K 350 . Kuat tekan beton pada korelasi umur beton dapat dihitung dengan rumus:

$$
\text { Kuat Tekan Beton }=\frac{\text { Kuat Tekan Beton } 7 \text { hari }}{\text { Korelasi }}
$$

\section{Persiapan Spesimen Baja Tulangan Beton ST 42}

Spesimen yang digunakan adalah baja tulangan beton ST 42 dengan diameter $10 \mathrm{~mm}$. Spesimen dipotong dengan ukuran panjang $100 \mathrm{~mm}$. Selanjutnya spesimen yang telah dipotong ini dihaluskan dengan ampelas besi. Permukaan 
yang telah halus dibersihkan dengan aquades, kemudian dikeringkan pada suhu kamar selama 10 menit. Setelah kering, spesimen ditimbang untuk mengetahui berat awal spesimen. Timbangan yang digunakan adalah timbangan digital Mettler Toledo dengan tingkat ketelitian 0,0001 gram.

\section{Pembuatan Beton Tanpa Menggunakan Larutan Inhibitor dan Menggunakan Larutan Inhibitor}

Terdapat 3 jenis inhibitor yang digunakan dalam penelitian ini, yaitu sodium nitrit, asam askorbat, dan asam karboksilat. Inhibitor tersebut dilarutkan dalam air dengan tiga variasi konsentrasi yang berbeda, yaitu 100 ppm, 200 ppm, dan 300 ppm.

Bahan-bahan yang digunakan untuk pembuatan beton adalah semen, pasir (agregat halus), kerikil (agregat kasar), dan air. Beton yang digunakan pada penelitian ini adalah beton dengan mutu K 350. Proses pembuatan beton diawali dengan penakaran bahan komposisi beton. Beton dicetak menggunakan pipa PVC dengan diameter 50,8 $\mathrm{mm}$ dan tinggi $100 \mathrm{~mm}$. Untuk beton yang menggunakan inhibitor, maka airnya menggunakan larutan inhibitor yang telah disiapkan sebelumnya.

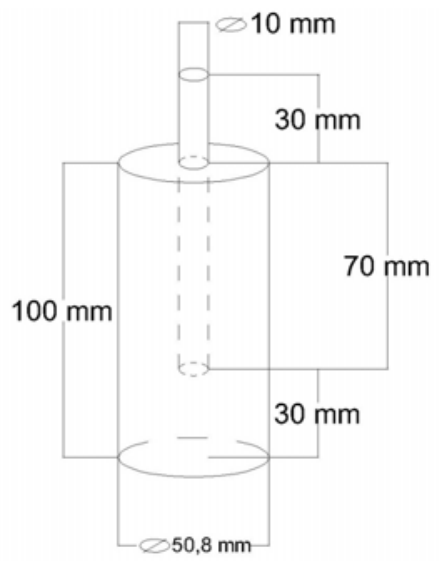

Gambar 1. Ukuran Spesimen Beton Bertulang

\section{E. Persiapan Larutan Induk Media Korosif Garam}

Larutan induk media korosif garam dibuat dengan salinitas 3,5 \%. Pada salinitas 3,5\%, perbandingan komposisi garam dan air adalah 35 gr pada $1000 \mathrm{ml}$ air. Garam yang digunakan adalah garam $\mathrm{NaCl}$ (Natrium Chlorida) dan air yang digunakan adalah aquades.

\section{F. Proses Perendaman Spesimen}

Proses perendaman spesimen dilakukan pada larutan induk media korosif garam dengan salinitas 3,5 \% yang telah disiapkan sebelumnya. Ketinggian air untuk perendamannya adalah setinggi $75 \mathrm{~mm}$. Pada penelitian ini, proses perendaman dilakukan selama 14 hari.

Proses pengujian ini mengacu pada ASTM C 876 ${ }^{[15]}$. Pengujian ini dilakukan menggunakan arus DC $6 \mathrm{~V}$ yang berasal dari rectifier sebagai alat bantu mempercepat korosi pada spesimen beton bertulang. Spesimen beton bertulang diperlakukan sebagai anoda, sedangkan katodanya menggunakan karbon grafit. Proses ini bertujuan untuk mempercepat perpindahan ion $\mathrm{Fe}^{+}$dan elektronnya.

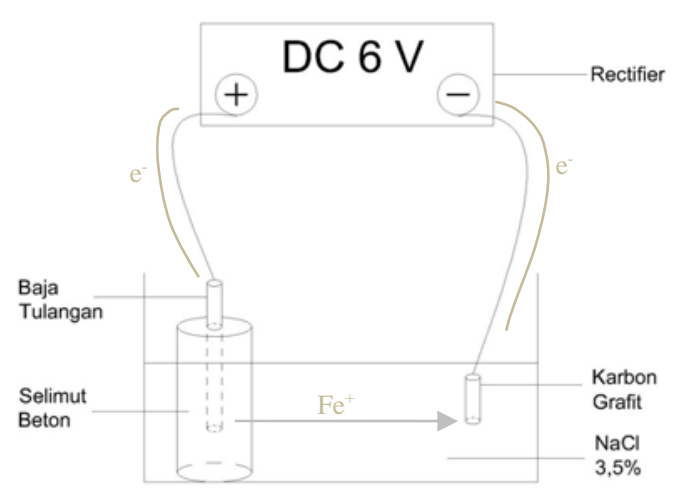

Gambar 2. Mekanisme Pengujian Korosi dengan Mengaliri Arus

\section{G. Uji Laju Korosi}

Dalam penelitian ini, uji laju korosi dihitung menggunakan metode weight loss. Untuk mengukur laju korosi pada spesimen baja tulangan beton ST 42, maka harus dicari berat yang hilang akibat korosi. Sebelum mengukur berat yang hilang pada baja tulangan beton ST 42, langkah yang harus dilakukan adalah pembongkaran beton. Pembongkaran beton ini bertujuan untuk mengambil baja tulangan beton ST 42 yang telah mengalami korosi akibat direndam dalam larutan induk media korosif garam $\mathrm{NaCl}$ salinitas 3,5\% dan dialiri arus DC $6 \mathrm{~V}$.

\section{H. Penentuan Efisiensi Inhibisi}

Pada penelitian ini perlu dicari inhibitor apa dan dengan konsentrasi berapa yang paling efisien dalam menghambat laju korosi.

\section{Pengamatan Struktur Mikro}

Pengamatan struktur mikro dilakukan untuk mengetahui apa yang terjadi pada sampel spesimen setelah diuji. Pengamatan dilakukan menggunakan alat khusus yang bernama mikroskop mikro.

Untuk melakukan pengamatan struktur mikro, permukaan spesimen dihaluskan terlebih dahulu. Proses pemolesan dilakukan dengan menggunakan partikel abrasif tertentu yang berperan sebagai alat pengiris secara berulang-ulang. Partikel abrasive tersebut disatukan dalam lembar kertas yang biasa disebut dengan kertas amplas. Proses pemolesan ini menggunakan kertas amplas dan mesin poles Buehler Ecomet III Polisher Grinder. Kertas amplas yang digunakan adalah kertas amplas nomor 80, 120, 240, 320, 500, 600, 800, 1000, 1200, 1500, dan 2000.

Spesimen yang telah selesai dipoles selanjutnya dibilas menggunakan HNO3 dan alkohol untuk membersihkan sisa noda yang masih menempel pada permukaan specimen. Selanjutnya dikeringkan menggunakan alat pengering. Spesimen yang telah kering siap untuk dilakukan pengamatan struktur mikro. Pengamatan struktur mikro menggunakan mikroskop mikro yang terhubung dengan kamera beresolusi 5 megapixel. Pengamatan ini bertujuan untuk mengetahui jenis korosi apa yang terjadi pada spesimen yang diuji. 


\section{ANALISA DAN PEMBAHASAN}

\section{A. Pengujian Kuat Tekan Beton}

Tugas akhir ini diawali dengan pemahaman materi melalui apa yang didapatkan penulis di mata kuliah Korosi. Kemudian dilanjutkan dengan mempelajari buku, jurnal, proseding, dan tugas akhir terdahulu yang membahas tentang permasalahan yang berhubungan dengan tugas akhir ini. Literatur tersebut digunakan sebagai referensi dalam penulisan tugas akhir ini.

\section{B. Pengamatan Visual}

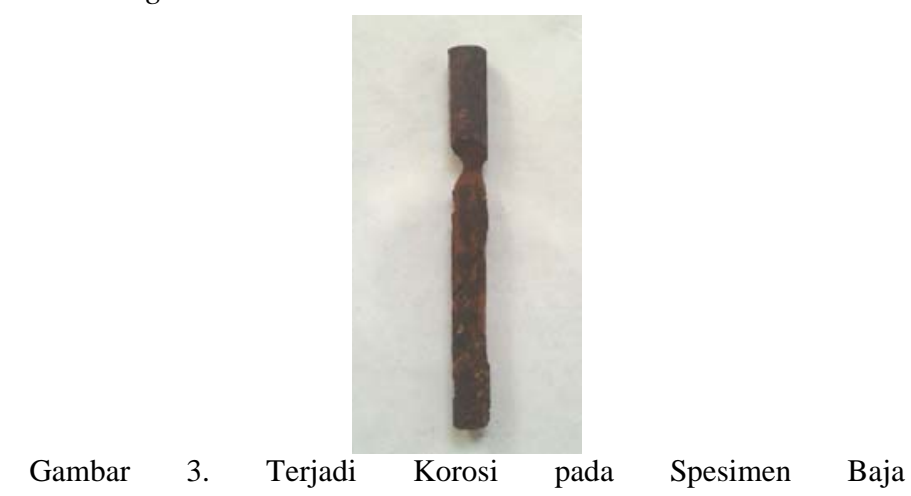

Tulangan Beton ST 42

Dalam proses terjadinya korosi pada baja tulangan beton ST 42 yang diteliti, beton yang direndam tersebut akan mengalami penetrasi atau difusi dari larutan induk media korosif garam. Hal ini dapat mempengaruhi nilai dari resistensi yang dimiliki oleh beton tersebut ketika dialiri arus dan kadar $\mathrm{O}_{2}$ yang ada pada larutan memiliki peranan dalam proses oksidasi terhadap baja tulangan sehingga terjadi korosi. Dapat dilihat dari gambar 3 bahwa pada spesimen baja tulangan beton ST 42 telah mengalami perubahan yang diakibatkan oleh korosi.

\section{Uji Laju Korosi}

Dari data laju korosi baja tulangan beton ST 42 pada beton bertulang tanpa menggunakan inhibitor dan menggunakan inhibitor sodium nitrit, asam askorbat, dan asam karboksilat dengan variasi konsentrasi inhibitor diatas, menunjukkan bahwa laju korosi pada spesimen bertulang tanpa menggunakan inhibitor akan menurun ketika ditambahkan inhibitor ke dalam spesimen betonnya. Dapat dilihat juga bahwa semakin tinggi konsentrasi inhibitor maka semakin rendah laju korosinya.

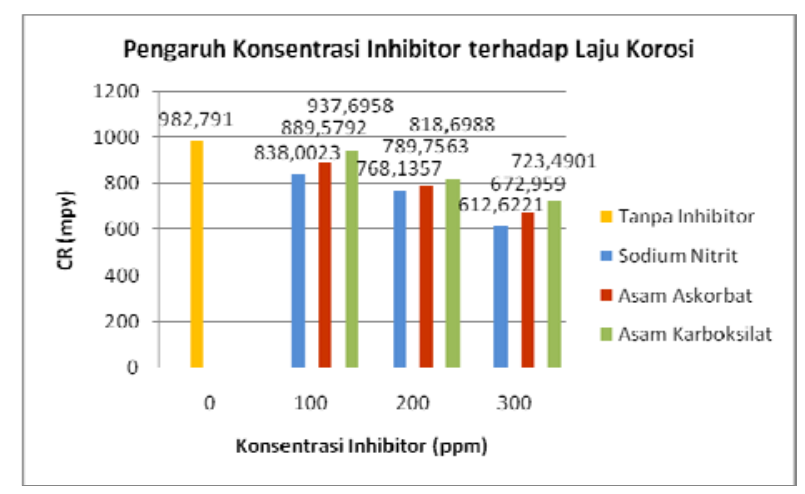

Gambar 4. Diagram Pengaruh Konsentrasi Inhibitor terhadap Laju Kotosi

Hal ini disebabkan karena semakin tinggi konsentrasi inhibitonya, maka lapisan oksida tipis yang akan terbentuk diatas permukaan baja tulangan akan semakin melindungi baja tulangan dari korosi.

\section{Penentuan Efisiensi Inhibisi}

Dalam penelitian tugas akhir ini, telah diketahui laju korosi pada masing-masing spesimen yang diuji, baik pada spesimen beton bertulang tanpa menggunakan inhibitor, maupun pada spesimen beton bertulang menggunakan inhibitor. Namun dari semua spesimen tersebut, perlu dicari inhibitor apa dan dengan konsentrasi berapa yang paling efisien dalam menghambat laju korosi.

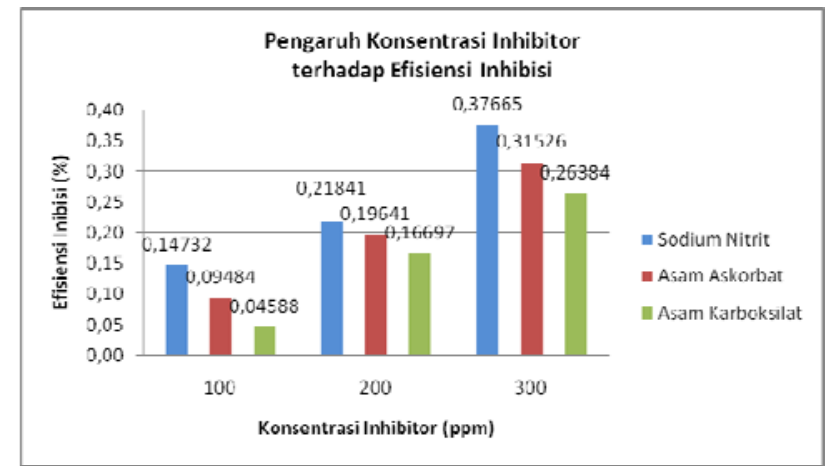

Gambar 5. Diagram Pengaruh Konsentrasi Inhibitor terhadap Efisiensi Inhibisi

Dari pengolahan data efisiensi inhibisi baja tulangan beton ST 42 pada beton bertulang menggunakan inhibitor sodium nitrit, asam askorbat, dan asam karboksilat dengan variasi konsentrasi inhibitor diatas, menunjukkan bahwa kondisi optimal yang efisiensi inhibisinya tertinggi adalah inhibitor sodium nitrit dengan konsentrasi inhibitor 300 ppm. Hal ini disebabkan karena terbentuknya lapisan oksida tipis diatas permukaan baja tulangan yang akan melindungi baja tulangan dari korosi.

\section{E. Pengamatan Struktur Mikro}

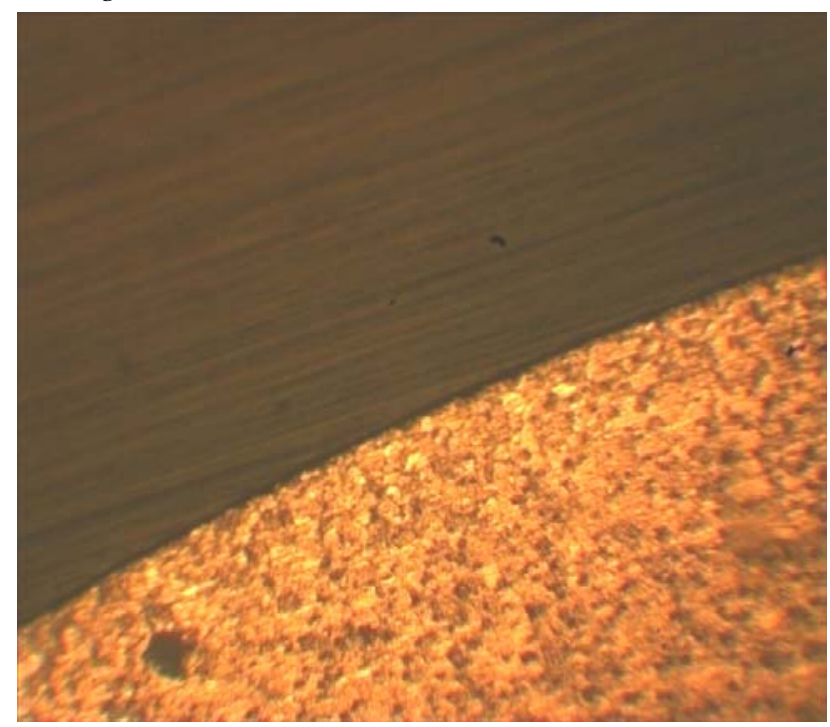


Gambar 6. Foto Struktur Mikro Perbesaran 100 X Baja Tulangan Beton ST 42 Sebelum Uji Korosi

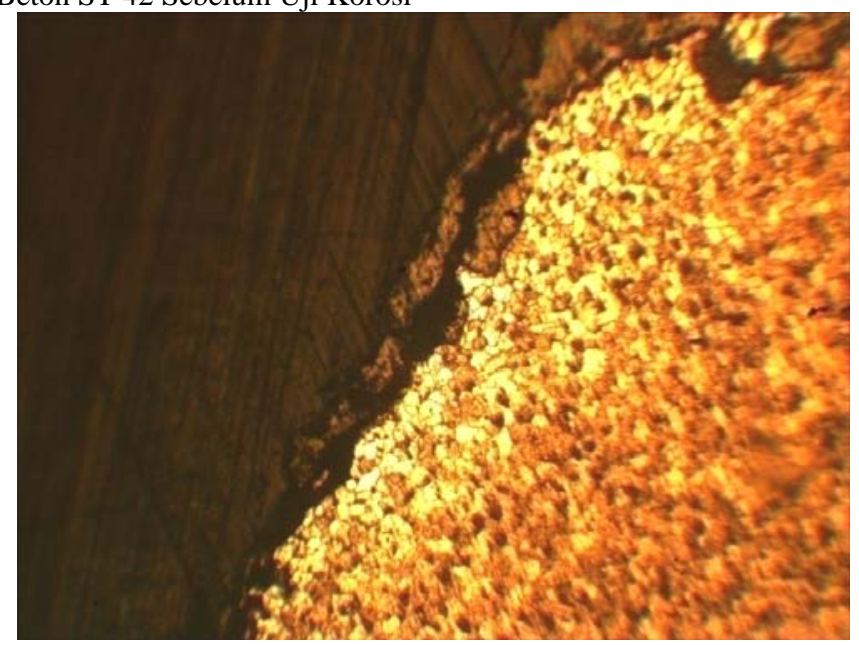

Gambar 7. Foto Struktur Mikro Perbesaran 100 X Baja Tulangan Beton ST 42 pada Beton Bertulang Menggunakan Inhibitor Sodium Nitrit Konsentrasi 300 ppm Setelah Uji Korosi

Dari gambar 6 dan 7 dapat dilihat bahwa terjadi perubahan struktur mikro pada baja tulangan sebelum dan sesudah pegujian korosi. Dapat dilihat pada gambar 4.9 bahwa terdapat celah pada permukaan baja tulangan beton ST 42 tersebut yang memperlihatkan bahwa telah terjadi korosi. Jika dilihat kasat mata, korosi ini hanya terlihat seperti bintik hitam. Korosi tersebut sangat berbahaya karena dapat merusak struktur logam dan merupakan awal mula dari keretakan suatu logam.

\section{KESIMPULAN/RINGKASAN}

Berdasarkan analisa yang telah diuraikan pada BAB IV, maka dapat diambil kesimpulan sebagai berikut:

1. Pengaruh inhibitor sodium nitrit, asam askorbat, dan asam karboksilat dengan konsentrasi inhibitor 100 ppm, 200 ppm, dan 300 ppm terhadap laju korosi baja tulangan beton ST 42 di kondisi lingkungan media korosif garam dengan metode weight loss, dari data eksperimen menunjukkan bahwa semakin tinggi konsentrasi inhibitornya maka semakin rendah laju korosinya.

2. Kondisi optimal pengaruh variasi inhibitor dan konsentrasi inhibitor terhadap laju korosi pada baja tulangan ST 42 di kondisi lingkungan laut yang efisiensi inhibisinya tertinggi adalah baja tulangan beton ST 42 pada beton bertulang menggunakan inhibitor sodium nitirt dengan konsentrasi 300 ppm, yaitu sebesar 0,37665 \%.

\section{UCAPAN TERIMA KASIH}

Penulis mengucapkan terima kasih kepada Bapak Herman Pratikno, S.T., M.T., Ph.D. selaku Dosen Pembimbing I dan Bapak Dr. Ir. Hasan Ikhwani, M.Sc. selaku Dosen Pembimbing II atas segala bimbingan, nasehat, saran, dan kritiknya yang sangat membantu penulis dalam menyelesaikan Tugas Akhir ini. Penulis juga mengucapkan terimaksih kepada karyawan teknisi Laboratorium Korosi dan Analisa Kegagalan
Jurusan Teknik Material dan Metalurgi ITS, karyawan teknisi Laboratorium Beton dan Bahan Bangunan Jurusan Teknik Sipil ITS, dan karyawan teknisi Laboratorium Konstruksi dan Kekuatan Jurusan Teknik Perkapalan ITS yeng telah membantu dan mengarahkan penulis dalam melaksanakan penelitian Tugas Akhir ini. Penulis juga tidak lupa mengucapkan terimakasih kepada semua pihak yang sudah membantu dalam penyelesaian tugas akhir ini secara langsung maupun tidak langsung.

\section{DAFTAR PUSTAKA}

[1] Bahri, S. 2007. Penghambatan Korosi Baja Beton dalam Larutan Garam dan Asam dengan Menggunakan Campuran Senyawa Butilamina dan Oktilamina. Jurnal Gradien Vol.3 No.1. Program Studi Teknik Sipil, Universitas Bengkulu. Bengkulu.

[2] Juliawati, M. 2003. Pengaruh Inhibitor Asam Karboksilat Terhadap Laju Korosi Baja Tulangan ST 37 serta Pengaruhnya terhadap Kuat Tekan Beton (Mutu Beton K350). Skripsi Departemen Sipil Fakultas Teknik, Universitas Indonesia. Depok.

[3] Herdiansjah, A. 2003. Pengaruh Penambahan Inhibitor Kalsium Nitrit ke Dalam beton Bertulang Terhadap Kuat Tekan Beton dan Laju Korosi Baja Tulangan. Skripsi Departemen Sipil Fakultas Teknik, Universitas Indonesia. Depok.

[4] Surdia, dkk. 1979. Efek Inhibitor Terhadap Sifat Korosi Paduan Logam Cu Oleh Air Laut. Korosi 1. Indonesia.

[5] Nikitasari, A., Anwar, M. S., Mabruri, E., Sundjono. 2014. Pengaruh Sodium Nitrit Sebagai Inhibitor Korosi Baja Tulangan Beton Di Dalam Larutan Beton Buatan pH 7 yang Terkontaminasi Klorida. Prosiding Penguasaan Teknologi Material dan Metalurgi Untuk Menuju Kemandirian Industri Nasional. Tanggerang.

[6] Halomoan, P. J. 2003. Pengaruh Inhibitor Asam Askorbat Terhadap Laju Korosi Tulangan Beton Mutu ST 37 dan Kekuatan Tekan Beton K350. Skripsi Departemen Sipil Fakultas Teknik, Universitas Indonesia. Depok.

[7] Aziz, M. M., Kurniawan, B. A. 2013. Pengaruh Konsentrasi Inhibitor Suplemen Vitamin C (Asam Askorbat) terhadap Laju Korosi Baja Api 5I Grade $\mathrm{B}$ pada Lingkungan 3,5\% $\mathrm{NaCl}$ yang Mengandung $\mathrm{Gas} \mathrm{CO}_{2}$. JURNAL TEKNIK POMITS Vol. 2, No. 1, Jurusan Teknik Material dan Metalurgi, Fakultas Teknologi Industri, Institut Teknologi Sepuluh Nopember. Surabaya.

[8] Rarasati, A. D. 2003. Pengaruh Penambahan Inhibitor Phospate Dalam Beton Bertulang Mutu K-350 dan ST 37 Terhadap Kekuatan Beton dan Laju Korosi Tulangan. Skripsi Departemen Sipil Fakultas Teknik, Universitas Indonesia. Depok.

[9] Fontana, M. G. 1987. Corrosion Engineering Third Edition. Department of Merallurgical Engineering. The Ohio State University. Ohio.

[10] Fardhyanti, D. S., 2004. UJI EFEKTIVITAS NATRIUM FOSFAT SEBAGAI INHIBITOR PADA KOROSI BAJA TULANGAN BETON. Jurusan Kimia, Fakultas MIPA, Universitas Negeri Semarang. Semarang.

[11] American Society for Testing and Materials. 2004. G 31 - 72 Standard Practice for Laboratory Immersion Corroosion Testing of Metals. ASTM Society.

[12] Nasution, Y. R. A., Hermawan, S., Hasibuan, R. 2012. Penentuan Efisiensi Inhibisi Reaksi Korosi Baja Menggunakan Ekstrak Kulit Buah Manggis (Garciana mangostana L). Jurnal Teknik Kimia USU, Vol.1, No.2 (2012). Departemen Teknik Kimia, Fakultas Teknik, Universitas Sumatra Utara. Medan.

[13] Laboratorium Beton dan Bahan Bangunan. 2014. Buku Petunjuk Praktikum Teknologi Beton dan Bahan. Jurusan Teknik Sipil, ITS. Surabaya.

[14] American Society for Testing and Materials. 2014. C39/C39M Standard Test Method for Compressive Strength of Cylindrical Concrete Specimens. ASTM Society.

[15] American Society for Testing and Materials. 1999. C876 Standard Test Method for Half-Cell Potentials of Uncoated Reinforcing Steel in Concrete. ASTM Society. 